Endocrinol. Japon. 1966, 13 (3), 319 325

\title{
EFFECT OF SUCKLING ON THE FSH AND LH CONTENT \\ OF THE ANTERIOR PITUITARY IN THE GASTRATED PUERPERAL RAT*
}

\author{
TAKashi KOBAYASHI, TAKuRo KOBAYASHI and Nobuo NAGAI \\ Department of Obstetrics and Gynecology, School of Medicine, \\ University of Tokyo, Tokyo
}

\begin{abstract}
SYNOPSIS
Many clinical and experimental data suggest that suckling can modify reproductive function. Among these are lactation amenorrhea, lactation diestrum and inhibition of castration changes in the anterior pituitary glands in puerperal rats. In the present work, FSH and LH content of the anterior pituitary glands in suckling and non-suckling rats following gonadectomy were assayed by means of the modified HCG-augmentation method of Steelman-Pohley and the modified OAAD method of Parlow, respectively. The results were as follows: (1) On Day 3 postpartum, all the mothers were gonadectomized and divided into the suckling and non-suckling groups. On Day 17 postpartum, they were sacrificed and pituitary FSH and LH content were bioassayed. The litters had a normal increase in body weight during the experimental period after the mothers were gonadectomized. (2) Both pituitary FSH and LH content in the castrated non-suckling group were approximately as high as the levels found in the simple castrated adult female rat. Those in the castrated suckling group were lowered to levels approximately equal to those in the intact suckling rats. The gonadotrophins of the suckling groups were significantly different from those in the non-suckling groups. Histological findings of the anterior pituitary glands were in agreement with the functional changes observed. The present data confirm that suckling plays an important inhibitory role in pituitary gonadotrophin (FSH and LH) secretion in castrated puerperal rats. More physiological and useful therapeutic methods for the study of some reproductive disfunctions might be found through investigation of this mechanism, probably involving hypothalamico-hypophysial process.
\end{abstract}

Numerous findings support the theory that reproductive function is controlled by the hypothalamico-hypophysio-gonadal system. In addition, suckling is effective in regulating reproductive function as evidenced by such phenomena as lactation amenorrhea and inhibition of the development of castration cells and of the increase in gonodotrophic potency in the anterior pituitary of some mammals. These facts are of interest since they suggest the existence of another regulating mechanism other than the sex-steroids for reproductive function.

According to our previous study (1965), pituitary FSH and LH content in the castrated adult female rats increased significantly, while in the puerperal lactating

Received for publication July 4, 1966.

* This work was supported in part by a Grant-in-Aid for Scientific Research from the Ministry of Education and a grant from the Population Council, N.Y. (Grant No. M-65, 117). 
rats, both appeared to be suppressed by the suckling stimuli.

The effects of suckling on the pituitary FSH and LH content in the castrated puerperal rats were investigated in order to ascertain the net effect of both the stimulatory influence of castration and the inhibitory influence of the suckling stimulus on the gonadotrophin content of anterior pituitary glands.

\section{MATERIALS AND METHODS}

Adult female rats of the Wistar strain were mated, housed in individual cages and provided with a diet complex (Oriental Co.) and water ad lib. Until day-3 postpartum, the rats had normal lactation. On day-3 postpartum, all mothers were bilaterally ovariectomized and divided into two groups: a non-suckling (I) and a suckling (II). In the latter, litters were limited to 6 in number to standardize the suckling stimuli. Normal (non-castrated) suckling puerperal rats were used as a control group III.

On day-17 postpartum (the 14th day after gonadectomy) all mothers were sacrificed by decapitation. The anterior pituitary glands were dissected out, weighed on a torsion balance and homogenized immediately with cold acetone. The homogenizer was kept in an acetone-dry ice mixture and left in the refrigerator overnight. After centrifugation, the precipitates were lyophilized. This acetone powder was pooled and stored in a deepfreezer until assayed. Adrenals and uteri were weighed and fixed in $10 \%$ formalin for histological preparation (stained by PAS or hematoxylin-eosin). Some of the pituitaries were also fixed and stained in the same manner.

The litters were weighed initially and at the end to ascertain their body growth during this experimental period.

\section{Bioassay}

(1) FSH assay

The FSH content of the pooled powder of anterior pituitary glands from 10 rats was assayed by the modified HCG-augmentation method of Steelman-Pohley (1953). The modifications were as follows: immature female rats of the Sprague-Dawley strain were used as assay animals. NIHFSH-S3 as a standard and the prepared powder of anterior pituitary glands were dissolved in physiological saline at appropriate concentrations and were injected subcutaneously in a volume of $0.5 \mathrm{~m} l$ twice a day for 3 successive days. Each animal received a total volume of $3.0 \mathrm{ml}$; and a $25 \mathrm{I}$.U. of HCG had been added to each $3 \mathrm{~m} l$ sample. Six rats were used at each dose level and a five point assay was utilized. The dose-response relationship was plotted as the increase of ovarian weight against the total dose of FSH.

(2) LH-assay

The LH content of the pooled powder of anterior pituitary grands from 10 rats was determined by the $4 \mathrm{hr}$, 1-ovary modification of the ovarian ascorbic acid depletion assay as described by Parlow (1961). The 25-day-old assay animals were injected subcutaneously with $75 \mathrm{I}$.U. of PMS and 60 hrs. later with 30 I.U. of HCG. Six days after HCG administration, each rat was anesthetized lightly with ether and injected into the femoral vein with saline containing standard or test materials, $1 \mathrm{~m} l$ per $100 \mathrm{gr}$ of body weight. Four hours later, the left ovary was removed, trimmed, weighed and ascorbic acid content was measured by the method of Schaffert and Kingsley (1955). Six immature female rats of the Wistar-Imamichi strain were used at each dose level. A four point assay was performed, that is, the assay included 2 doses of both standard (HIN-LH-S8) and unknown with a 4-fold interval between successive doses. All potencies were calculated using standard statistical methods (Bliss. 1956). 


\section{RESULTS}

All mothers showed normal increases in body weight. Weights of overies (on Day-3 postpartum), and uteri and adrenals (on Day-17 postpartum) in the castrated non-suckling group were not significantly different from those in the castrated suckling group. However, the weight of the anterior pituitary glands in the former group was significantly higher than that in the latter.

The litters of the castrated suckling group had a normal weight gain showing that the mothers had an adequate milk supply.

(1) FSH content of the anterior pituitary glands

In the castrated non-suckling group, the FSH content was high, approximately equal to that reported for the simple castrated adult female rat. In the castrated suckling group, it fell to approximately as low a level as that found in noncastrated suckling puerperal rats. The two suckling groups are significantly different from the non-suckling (see Table 2 and Fig. 1).

Table 1. Numbers and organ weights of the castrated suckling, non-suckling rats and non-castrated suckling rats

\begin{tabular}{|c|c|c|c|c|c|c|c|c|c|c|c|}
\hline \multirow{3}{*}{ Group } & \multicolumn{7}{|c|}{ MOTHERS } & \multicolumn{4}{|c|}{ LITTERS } \\
\hline & \multirow{2}{*}{$\begin{array}{l}\text { No. } \\
\text { of } \\
\text { rats }\end{array}$} & \multicolumn{2}{|c|}{ body wt. $(\mathrm{g})^{*}$} & \multirow{2}{*}{$\begin{array}{c}\text { ovarian* } \\
\text { wt. } \\
\text { (mg) }\end{array}$} & \multirow{2}{*}{$\begin{array}{c}\text { uterine* } \\
\text { wt. } \\
(\mathrm{mg})\end{array}$} & \multirow{2}{*}{$\begin{array}{l}\text { adrenal* } \\
\text { wt. } \\
\text { (mg) }\end{array}$} & \multirow{2}{*}{$\begin{array}{l}\text { ant. pit.* } \\
\text { wt. } \\
\text { (mg) }\end{array}$} & \multicolumn{2}{|c|}{ No. of litters* } & \multicolumn{2}{|c|}{ body wt. $(g)^{*}$} \\
\hline & & initial & final & & & & & birth & suckling & $g$ initial & final f.-i. \\
\hline $\begin{array}{c}\text { castrate } \\
\text { non-suckling }\end{array}$ & 10 & $\begin{array}{l}172.0 \\
\pm 8.3\end{array}$ & $\begin{array}{l}196.6 \\
\pm 6.8\end{array}$ & $\begin{array}{c}67.3 \\
\pm 2.15\end{array}$ & $\begin{array}{l}111.5 \\
\pm \quad 5.19\end{array}$ & $\begin{array}{l}58.7 \\
\pm 2.97\end{array}$ & $\begin{array}{c}6.98 \\
\pm 0.37\end{array}$ & $\begin{array}{l}9.2 \\
\pm 0.56\end{array}$ & - & $\begin{array}{l}6.8 \\
\pm 0.23\end{array}$ & \\
\hline $\begin{array}{l}\text { castrate } \\
\text { suckling }\end{array}$ & 10 & $\begin{array}{r}18.4 \\
\pm 7.6\end{array}$ & $\begin{array}{l}194.1 \\
\pm 8.5\end{array}$ & $\begin{array}{r}65.8 \dagger \\
\pm 2.71\end{array}$ & $\begin{array}{r}111.4 \\
\pm 6.61\end{array}$ & $\begin{array}{c}55.8 \\
\pm 2.88\end{array}$ & $\begin{array}{c}5.63 \\
\pm 0.56\end{array}$ & $\begin{aligned} & 8.4 \\
\pm & 0.42\end{aligned}$ & \pm & $\begin{array}{l}6.2 \\
\pm 0.20\end{array}$ & $\begin{array}{l}19.0 \\
\pm 0.45 \\
12.8\end{array}$ \\
\hline $\begin{array}{l}\text { non-castrate } \\
\text { suckling }\end{array}$ & 11 & $\begin{array}{l}196.2 \\
\pm 10.1\end{array}$ & $\begin{array}{l}192.3 \\
\pm 7.2\end{array}$ & $\begin{array}{c}58.5 \\
\pm 2.88\end{array}$ & $\begin{array}{l}180.1 \\
\pm 11.6\end{array}$ & $\begin{array}{l}59.7 \\
\pm 3.15\end{array}$ & $\begin{array}{l}6.13 \\
\pm 0.51\end{array}$ & $\begin{aligned} & 9.0 \\
\pm & 0.45\end{aligned}$ & \pm & $\begin{array}{l}6.1 \\
\pm 0.19\end{array}$ & $\begin{aligned} & 19.3 \\
\pm & 0.55^{13.2}\end{aligned}$ \\
\hline
\end{tabular}

Table 2. Anterior pituitary weight and FSH content in the castrated suckling, non-suckling rats and non-castrated suckling rats

\begin{tabular}{lcccc}
\hline Group & $\begin{array}{c}\text { No. of } \\
\text { rats }\end{array}$ & $\begin{array}{c}\text { ant. pit. wt. } \\
(\mathrm{mg}) *\end{array}$ & $\begin{array}{c}\text { FSH } \\
(\mu \mathrm{g} / \mathrm{gland}) * *\end{array}$ & $\begin{array}{c}95 \% \text { confidence } \\
\text { limits }\end{array}$ \\
\hline $\begin{array}{c}\text { castrate } \\
\text { non-suckling } \\
\text { castrate } \\
\text { suckling }\end{array}$ & 10 & $6.98 \pm 0.37$ & $183.4 \dagger$ & $154.9 \sim 214.0$ \\
$\begin{array}{c}\text { non-castrate } \\
\text { suckling }\end{array}$ & 10 & $5.63 \pm 0.56$ & $82.5 \dagger$ & $72.6 \sim 92.8$ \\
\hline$*$ mean \pm S.E. of mean. & $7.26 \pm 0.48$ & $53.6 \dagger \dagger$ & $29.5 \sim 80.0$ \\
$\dagger 5$ point assay. & $* * \mu \mathrm{g} /$ gland of NIH-FSH-SI. & \\
\end{tabular}




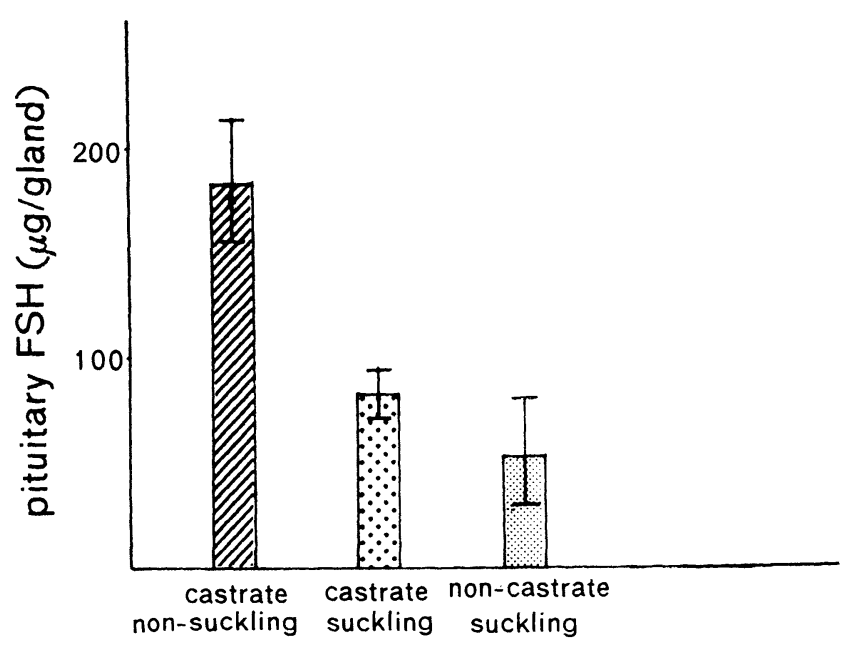

Fig. 1. Pituitary FSH content in the castrated suckling, non-suckling rats and non-castrated suckling rats.

Columns are the mean values and vertical lines $95 \%$ confidence limits.

(2) LH content of the anterior pituitary glands

Results were similar to those found for FSH content, that is, pituitary LH content in the castrated suckling group was significantly lower than that in the castrated non-suckling group (see Table 3 and Fig. 2). Histological findings of the anterior pituitary agreed with these functional data; in the castrated nonsuckling group, a number of typical basophilic hypertrophied castration cells were found while in the castrated suckling group, these cells were almost completely absent. These data support the interpretation that suckling suppressed the effects of castration (development of castration cells and elevation of FSH and LH potency) in the anterior pituitary glands in gonadectomized puerperal rats.

Table 3. Anterior Pituitary weight and LH content in the castrated suckling, non-suckling rats and non-castrated suckling rats

\begin{tabular}{|c|c|c|c|c|}
\hline Group & $\begin{array}{l}\text { No. of } \\
\text { rats }\end{array}$ & $\begin{array}{l}\text { ant. pit. wt. } \\
(\mathrm{mg})\end{array}$ & $\begin{array}{c}\text { L.H. } \\
(\mu \mathrm{g} / \text { gland }) * *\end{array}$ & $\begin{array}{l}95 \% \text { confidence } \\
\text { limits }\end{array}$ \\
\hline $\begin{array}{l}\text { castrate } \\
\text { non-suckling }\end{array}$ & 10 & $6.98 \pm 0.37$ & 37.2 & $30.0 \sim 46.0$ \\
\hline $\begin{array}{l}\text { castrate } \\
\text { suckling }\end{array}$ & 10 & $5.63 \pm 0.56$ & 15.5 & $12.5 \sim 19.1$ \\
\hline $\begin{array}{l}\text { non-castrate } \\
\text { suckling }\end{array}$ & 11 & $7.26 \pm 0.48$ & 10.4 & $7.6 \sim 14.4$ \\
\hline
\end{tabular}




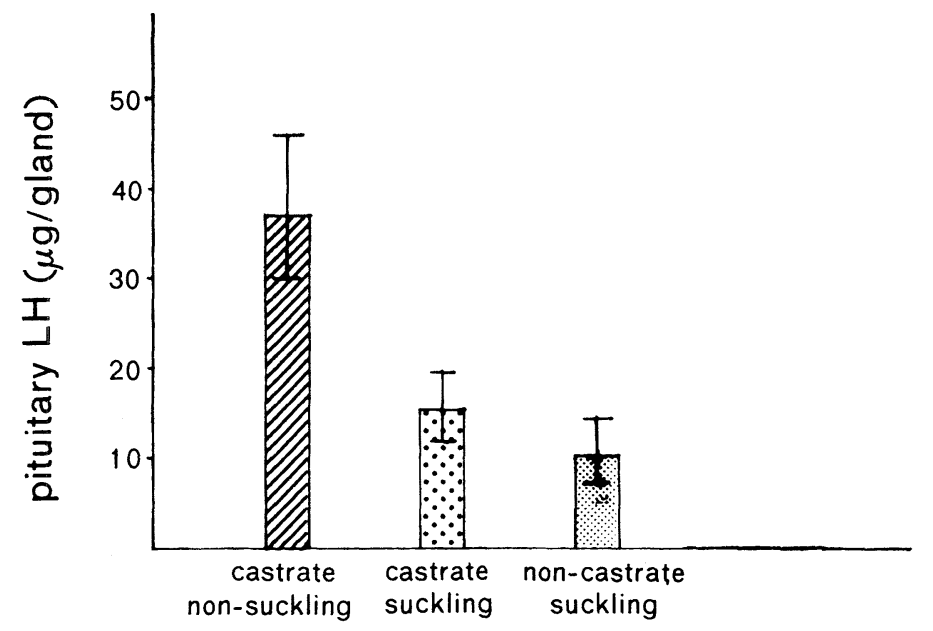

Fig. 2. Pituitary LH content in the castrated suckling, non-suckling rats and non-castrated suckling rats. Columns are the mean values and vertical lines $95 \%$ confidence limits.

\section{DISCUSSION}

Numerous observations have supported the concept that reproductive function is controlled by the hypothalamico-hypophysio-gonadal system, (Harris, 1955 and 1964; Kobayashi, 1956), and that gonadectomy, deficiency of sex-steroids, results in castration changes that is, development of castration cells and a marked increase of gonadotrophic potency in the anterior pituitary glands through the feed-back action to hypothalamico-hypophyseal axis (Fichera, 1905; Addison, 1917; Evans and Simpson, 1929; Hohlweg and Dohrn, 1932; Ellison and Wolfe, 1934 and 1935; Hohlweg, 1936 ; Westman, 1937; Kobayashi, 1940, 1952, 1956 and 1965; Greep and Johnes, 1950; Parlow, 1964).

The suggestion that suckling affects reproductive function in mammals is documented by clinical observations, such as amenorrhea during lactation as well as many experimental findings. Haterius (1932) found characteristic histologic changes in the pituitary during lactation, and attributed them of the influence of the persisting corpora lutea of lactation. According to the Desclin's (1936, 1940, 1945 and 1947) and our (1941) findings, however, these changes did not disappear after gonadectomy in the rat if suckling was allowed, that is, the basophils did not increase either in size and in number after castration as they regularly did in the non-suckling rats. Moreover, Desclin and Grégoire (1937) implanted immature ovaries into the kidneys of spayed lactating and non-lactating rats. In lactating animals, the implants remained small and contained young follicles without corpora lutea, whereas in non-lactating rats, they enlarged greatly and were filled with a number of corpora lutea. It was considered that lactation interfered with the gonadotropic activity of the pituitary and that prolactin was not a definite 
factor to this effect on the basis of other experiments including administration of prolactin (Desclin, 1947).

Experimental findings using intrasplenically transplanted immature ovaries in puerperal rats led to the same conclusion (Imamichi, 1954; Ito, 1960). Ito (1960) assayed the total gonadotrophin content of the pituitary in spayed puerperal rats and showed that the content was markedly lowered by lactation.

Rothchild (1960) proposed that suckling suppresses FTH (FSH+LH) secretion via the central nervous system (CNS).

From the experimental findings of effects of suckling on intraocular ovarian isotransplants in ovariectomized mice, Sadler and Browning (1961) suggested that release of FSH from the pituitary continued at a low level in lactating mice, and LH release did not occur over most of the lactation interval.

In the present study, these findings were re-examined by means of simultaneous bioassays of both FSH and LH content in the anterior pituitary glands in castrated suckling and non-suckling rats. Both FSH and LH content were markedly elevated in non-suckling puerperal rats following gonadectomy and were suppressed significantly by adequate suckling stimuli. In addition, gonadectomy, by removing functional corpora lutea of lactation, did not inhibit suckling or the development of litters during the experimental period.

These results present confirmatory evidnce that suckling, a non-steroidal stimulus, plays an important inhibitory role in castration effects in the anteror pituitary not only morphologically but also functionally, and it probably is capable of controlling some functions of reproduction. The suckling stimulus may evoke the production and release of some effective hypothalamic substance(s) to inhibit pituitary gonadotrophin secretion. The inter-relationship between these mechanisms and prolactin secretion would be worth investigating.

\section{SUMMARY}

Pituitary FSH and LH content of the anterior pituitary glands in suckling and non-suckling rats following gonadectomy were assayed by means of the modified HCG-augmentation method of Steelman-Pohley and the modified OAAD method of Parlow, respectively.

The results were as follows:

(1) On day 3 postpartum, all the mothers were gonadectomized and divided into the suckling and non-suckling groups. On Day 17 postpartum, they were sacrificed and pituitary FSH and LH content were bioassayed. The litters had a normal increase in body weight during the experimental period after the mothers were gonadectomized.

(2) Both pituitary FSH and LH content in the castrated non-suckling group were approximately as high as the levels found in the simple castrated adult female rat. Those in the castrated suckling group were lowered to levels approximately equal to those in the intact suckling rats. The gonadotrophins of the suckling groups were significantly different from those in the non-suckling groups.

Histological findings of the anterior pituitary glands were in agreement with the functional changes observed. 
The present data confirm that suckling plays an important inhibitory role in pituitary gonadotrophin (FSH and LH) secretion in castrated puerperal rats. More physilogical and useful therapeutic methods for the study of some reproductive disfunctions might be found through investigation of this mechanism, probably involving hypothalamico-hypophysial process.

\section{AGKNOWLEDGEMENT}

The authors wish to acknowledge the gifts of FSH and LH standard preparations by the Endocrinology Study Section of the National Institutes of Health, U.S.A.

\section{REFERENCES}

Addison, W.H.F. (1917). J. Comp. Neurol. 28, 441.

Bliss, C.I. (1956). Biometrics 12, 491.

Desclin, L. (1936). Compt. rend. soc. biol. 122, 447.

Desclin, L. (1940). Ibid. 133, 457.

Desclin, L. (1945). Arch. de biol. Paris. 56, 261.

Desclin, L. (1947). Endocrinology 40, 14.

Desclin, L. and C.H. Grégoire (1937). Compt. rend. soc. biol. 126, 250.

Ellison, E.T. and J.M, Wolfe (1934). Endocrinology 18, 555.

Ellison, E.T. and J.M. Wolfe (1935). Ibid. 19, 160.

Evans, H.M. and M.E. Simpson (1929). Am. J. Physiol. 89, 371.

Fichera, G. (1905). Arch. ital. biol. 43, 405.

Greep, R.O. and I.C. Johnes (1950). Recent Progr. in Horm. Research 5, 197.

Harris, G.W. Neural Control of the Pituitary Gland. London, Edward Arnold. (1955).

Harris, G.W. (1964). Endocrinology 75, 627.

Haterius, H.O. (1932). Anat. Record 54, 343.

Hohlweg, W. (1936). Klin. Wochschr. 15, 1832.

Hohlweg, W. (1936). Ibid. 15, 1907.

Hohlweg, W. and M. Dohrn (1932). Wien. Arch. inn. Med. 21, 337.

Imamichi, T., T. Eto and H. Hoshi (1954). Naibunpitu 1, 48. (In Japanese)

Ito, K. (1960). Journal of Japanese Obstetrical and Gynecological Society 12, 503. (In Japanese)

Kobayashi, T. (1940). Ibid. 35, 655. (In Japanese)

Kobayashi, T. (1941). Ikaishuho. 336, 9. (In Japanese)

Kobayashi, T. (1952). Naibunpitu no Tudoi. 1, 169. (In Japanese)

Kobayashi, T. (1956). The Studies on the Mechanism of the Reproductive Function. Report on the thema commissioned by Japanese Obstetrical and Gynecological Society. April. Tokyo (In Japanese)

Kobayashi, T., T. Kobayashi, M. Tsuyuguchi and N. Nagai. (1965). Endocrinol. Japon. 12, 289.

Parlow, A.F.: In Human Pituitary Gonadotropins. A. Albert. 111 Charles C. Thomas, Springfield, p. 300 (1961).

Parlow. A.F. (1964). Endocrinology 74, 489.

Rothchild, I. (1960). Ibid. 67, 9.

Sadler, W.A. and H.C. Browing. (1961). Proc. Soc. Exptl. Biol. Med. 106, 558.

Schaffert, R.R., and F.R. Kingsley. (1955). J. Biol. Chem. 212, 59.

Steelman, S.L. and F.M. Pohley. (1953). Endocrinology 53, 604.

Westman, A. (1937). Acta obst. gynec. scand. 17, 235. 